\title{
Corporate Water Footprint: Risks, Opportunities, and Management Options for Sustainable Development
}

\author{
N. Petrovic ${ }^{*}$, M. Cirovic \\ Center for Environmental Management and Sustainable Development, University of Belgrade Faculty of Organizational Sciences, \\ Belgrade, Serbia \\ *Corresponding author: petrovicn@fon.bg.ac.rs
}

Received January 01, 2013; Revised October 25, 2013; Accepted December 03, 2013

\begin{abstract}
For many companies, freshwater is a basic ingredient for their operations, while effluents may lead to pollution of the local hydrological ecosystem. Initially, public pressure has been the most important reason for sustainable business initiatives, but today many companies recognize that failure to manage the freshwater issue raises risks, including damage to the corporate image, threat of increased regulatory control, financial risks caused by pollution, or insufficient freshwater availability for operations. It is therefore interesting to know the specific water requirements of various consumer goods, particularly the water-intensive ones. This paper discusses specialised water reporting instruments such as the 'water footprint' calculation method and demonstrates it's usefulness in measuring and monitoring corporate sustainability. The water footprint analysis can highlight how near or far a company is from being sustainable and identify those aspects that have the greatest negative effect on freshwater and entire environment. Also it can highlights further management options and ways that companies address in their use of freshwater as one of the aspects of sustainable business performance, because today, many companies recognise that proactive environmental management contributes to their profitability and competitiveness in green markets.
\end{abstract}

Keywords: freshwater, sustainable development, water footprint, corporate waterfootprint

Cite This Article: N. Petrovic, and M. Cirovic, "Corporate Water Footprint: Risks, Opportunities, and Management Options for Sustainable Development." American Journal of Environmental Protection 1, no. 4 (2013): 120-123. doi: 10.12691/env-1-4-8.

\section{Introduction}

On the one hand, freshwater of adequate quality is not only a prerequisite for human societies, but also for natural ecosystems that perform functions essential for human existence and life on earth [1]. On the other hand, freshwater is a basic ingredient for many companies' operations, and effluents may pollute the local hydrological ecosystems. Many companies have addressed these issues and formulated proactive management strategies [2]. A company may face four serious risks related to failure to manage the freshwater issue: damage to the corporate image, the threat of increased regulatory control, financial risks caused by pollution and insufficient freshwater availability for business operations [3, 4].

Further on, responsible businesses are at the heart of society. Companies that understand their links with the communities they operate in, and their impact on the environment, are most likely to prosper in the long-term. At the same time, interests from stakeholders in firms' environmental performance and sustainable businesses are at an all-time high. There is an increasing recognition that good environmental performance makes good business sense [5] as well as the necessity of applying sustainable development.
Sustainable development is a global development management philosophy that aims to conserve the integrity of the Earth's ecosystems while supporting economic growth and social welfare, and therefore, is linked to ongoing economic growth and development [6]. It was developed by the Brundtland Commission during the World Commission on Environment and Development in 1987 [7]. Sustainable development has been defined in many ways, but the most frequently quoted definition is from Our Common Future, also known as the Brundtland Report: Sustainable development is development that meets the needs of the present without compromising the ability of future generations to meet their own needs. It contains within it two key concepts: the concept of needs, in particular the essential needs of the world's poor, to which overriding priority should be given; and the idea of limitations imposed by the state of technology and social organization on the environment's ability to meet present and future needs.

\section{Method}

Business water accounting is increasingly regarded as an essential part of sustainable corporate performance accounting. Since 2000, indicators for business water 
accounting have been proposed by the OECD and the WBCSD. During the past years the water footprint has started to receive recognition as a useful indicator of water use, within both governments and non-governmental organizations, as well as within businesses and media. The increased interest in the water footprint concept has prompted the question about what consumers and businesses can do to reduce their water footprint. Several instruments have been proposed, including a water label for water-intensive products, an international waterpricing protocol, an international business agreement on water-footprint accounting, and a Kyoto-protocol-like agreement on tradable water-footprint permits [8,9]. For freshwater, Hoekstra and Hung (2002) and Hoekstra and Chapagain (2006) have developed the concept of the water footprint that has been applied, among other things, for individual and national consumption comparisons [10,11].

The water footprint is an indicator of water use that looks at both direct and indirect water use of a consumer or producer. The water footprint of an individual, community or business is defined as the total volume of freshwater that is used to produce the goods and services consumed by the individual or community or produced by the business [12]. Water use is measured in terms of water volumes consumed (evaporated or incorporated into the product) and polluted per unit of time. A water footprint can be calculated for a particular product, for any welldefined group of consumers (e.g. an individual, family, village, city, province, state or nation) or producers (e.g. a public organization, private enterprise or economic sector). The water footprint is a geographically explicit indicator, not only showing volumes of water use and pollution, but also the locations. Compared to other water accounting tools, water footprint provides the most extended and complete water accounting method, since it includes both direct and indirect water use and considers both water consumption and pollution. It has already been applied for various purposes, such as the calculation of the water footprint of a large number of products from all over the world [13], but so far there have been few applications for business accounting.

The paper is based on data retrieved from variety of sources. It is inevitable that any errors in these sources can influence the result of this analysis. We have cross checked these data sources with other independent sources and found them to be consistent enough for this analysis.

\section{The Water Footprint Concept}

The water footprint concept is part of a larger family of concepts that have been developed in the environmental sciences over the past decade. A 'footprint' in general has become known as a quantitative measure showing the appropriation of natural resources by human being. The ecological footprint is a measure of the use of bioproductive space (hectares). The carbon footprint measures energy use in terms of the volume of carbon dioxide emissions (in tonnes). The water footprint measures water use (in cubic metres). In the mid-1990s, Rees and Wackernagel (1994) developed the concept of the 'ecological footprint' [14]. Their concern was to quantify the amount of space required to supply the world population with what they consume. The carbon footprint refers to the total amount of $\mathrm{CO}_{2}$ and other greenhouse gases emitted over the full life cycle of a product or service. A carbon footprint is usually expressed as a $\mathrm{CO}_{2}$ equivalent (in tonnes), in order to make the global warming effects of different greenhouse gases comparative and addable The roots of ecological footprint analysis lie in the search for an indicator that can show what proportion of the globe's biocapacity has been appropriated. The carbon footprint was formulated later to be able to quantify the contribution of various activities to climate change. The roots of water footprint analysis lie in the exploration of the global dimension of water as a natural resource. The starting point was the discontent with the fact that water resources management is generally seen as a local issue or a river-basin issue at most. By looking at the water use along production and supply chains, the water footprint aims to uncover this hidden link between human consumption and water use.

According to Hoekstra (2006) a water footprint consists of three components:

- the blue,

- green and

- grey water footprint [8].

The blue water footprint refers to the volume of 'blue water' (surface or ground water) that has been evaporated as a result of its appropriation for human purposes. It excludes the part of the water withdrawn from the ground or surface water system that returns to that system directly after use or through leakage before it was used.

The grey water footprint is the volume of polluted water that associates with the production of goods and services. It is calculated as the volume of water that is required to dilute pollutants to such an extent that the quality of the water remains above agreed water quality standards.

Water footprints are defined based on the actual water use per unit of product, not on the basis of global average numbers. This means that water footprints can only be calculated by analysing the source of products and considering the actual water use in the countries of origin (where production takes place) [8].

\section{Corporate Water Footprint}

Every business depends and impacts on freshwater resources: to process raw materials and manufacture goods, for cooling and cleaning, as a central ingredient in the goods they produce, or it is required to consume the product they sell. The future of business depends on the sustainability of water resources, which are increasingly under pressure. Globally, per capita availability of freshwater is steadily decreasing and the trend will inevitably continue as the world's population swells towards 9 billion, emerging economies increase consumption levels and climate change unfolds. For the global economy to carry on expanding at the same pace without improvements in efficiency, worldwide annual water consumption would have to rise from $4,500 \mathrm{~km}^{3}$ today to $6,900 \mathrm{~km}^{3}$ in 2030 - that is $40 \%$ above current accessible, reliable supply [15].

Corporate water footprint refers to the total volume of freshwater that is used directly and indirectly to run and support the business. It consists of two components: 
- the operational water footprint - the direct water use by the business in its own operations,

- the supply-chain water footprint - the water use in the business's supply chain.

Many businesses have a supply-chain water footprint that is much larger than the operational water footprint. This is particularly the case when a company does not have agricultural activity itself but is partly based on the intake of agricultural products (crop products, meat, milk, eggs, leather, cotton, wood/paper). When consumers use the products from a business, there can also be a water footprint in the end-use stage. That does not mean that the business can withdraw from some responsibility about what happens in the end-use stage.

Water footprint accounting is relevant for any sort of business, private or public. Business water footprint accounting can be applied for any coherent entity producing goods and/or services that are supplied to consumers or other businesses. It can be done for a private company or corporation, but also a governmental or nongovernmental organization or a public utility. It can be applied to various levels of scale, for instance a specific division of a company, an entire company or a whole business sector. Water footprint accounting can also be done for a project (e.g. construction of a piece of infrastructure) or activity (e.g. the organization of a large sports event).

Considering and mitigating the water footprint of business is a way to reduce risks:

- Physical risk: companies may increasingly face freshwater shortage in their supply chain or own operations.

- Reputational risk: the corporate image of a company will be damaged when questions arise among the public about whether the company properly addresses issues of sustainable and equitable water use.

- Regulatory risk: governmental interference and regulation in the area of water use will undoubtedly increase.

- Financial risk: above risks may translate into increased costs and/or reduced revenues [16].

Risks can turn into an opportunity for those companies that proactively respond to the challenge of global freshwater scarcity. Frontrunners that create product transparency before others do, that formulate specific and measurable targets with respect to water footprint reduction, with special attention to areas where problems of water scarcity and pollution are most critical, and that can demonstrate actual improvements, can turn this into a competitive advantage [16].

There is an increasing recognition that good environmental performance and sustainable sound business makes also good business sense. Further on, management of water as natural resource will affect current performance; failure to plan for a future in which environmental factors are likely to be increasingly significant may risk the long-term future of a business.

Companies that measure, manage and communicate their sustainable corporate performance are inherently well placed. They understand how to improve their processes, reduce their costs, comply with regulatory requirements and stakeholder expectations and take advantage of new market opportunities.
There is an increasing demand for company reporting that is sharper and more focused on the key impacts on the business and on the environment. It takes needed reporting of environmental performance, which will benefit in two ways:

- It will provide management information to help exploit the cost savings that, good environmental performance usually brings; and,

- It gives the chance to set out what is significant in firm's environmental performance.

ISO (The International Organization for Standardization) is considering the development of a new standard to provide internationally harmonized metrics for water footprints. Currently at the stage of a Preliminary Work Item (PWI), ISO 14046, Water footprint Requirements and guidelines, would complement existing standards on life cycle assessment (LCA) and ongoing work on carbon footprint metrics by ISO technical committee ISO/TC 207, Environmental management [17].

\section{Discussion}

There is no doubt that there are limits to the extent that humanity can continue to increase its appropriation of fresh water from the natural environment. Recent discussion has centered on the notion of a safe operating limit, being the level of global freshwater use beyond which widespread irreversible environmental change and harmful impacts on human well being are threatened. However, the issue is not only about planetary environmental boundaries, but also about equity, with consumption patterns in developed countries, underpinned by global supply chains, blamed for taking advantage of a disproportionate share of the Earth's scarce freshwater resources.

What is deceptive about freshwater use is that the vast majority, or around $90 \%$, is associated with the life cycles of products and services. Globally, withdrawals for the domestic sector are comparatively minor. This means that citizens consume a lot more water than they might realize and that their water footprints extend far beyond their local area and even national boundary. Due to the interconnectedness of global business, the local consumption of products and services is intervening in the hydrological cycle throughout the world and to an extent rarely understood or appreciated. As such, there has been much recent interest in the concept of water footprint, to make transparent the impacts of consumption and production on global freshwater scarcity, including a new ISO work program to develop a global water footprint standard - ISO/TC207/SC5/WG8 [17]. The interest in quantifying the environmental impacts related to products and services has also emerged in the area of life cycle assessment and life cycle management, led by the UNEPSETAC Life Cycle Initiative where a working group on water use is active. The importance of water footprinting has also been recognized by such organizations as the World Business Council for Sustainable Development and the UN Global Compact.

\section{Conclusions}

Due to the large proportion of current usage, humanity's water footprint must globally reduce by $48.6 \%$ 
to achieve the proposed stabilization target [18]. This reflects the extent to which global freshwater resources are currently being unsustainably utilized. Such a target may appear large, but is not unrealistic considering the potential for water productivity improvements in agriculture, industry and economy.

Importantly, efforts to reduce water footprints should be guided to the more urgent actions and the more each water volume reduced contributes to footprint reduction. It is also likely that water-intensive production will need to decrease in regions of high water stress and increase in regions where water stress is currently low and potential exists for increased levels of sustainable withdrawal.

\section{References}

[1] R., Costanza, H.E. Daly, Natural capital and sustainable development, Conservation Biology, 1992, 6: 37-46.

[2] P.W. Gerbens-Leenes, H.C. Moll, A.J.M. Schoot Uiterkamp, Design and development of a measuring method for environmental sustainability in food production systems, Ecol Econ, 2003, 46:231-248.

[3] D.A. Rondinelli, M.A. Berry, Environmental citizenship in multinational corporations: social responsibility and sustainable development, Eur Manag J, 2003, 18(1):70-84.

[4] WWF, A water scarcity risk-a typology, World Wildlife Fund, Godalming, 2007.

[5] D. Slović, N. Petrović, Environmental performance indicators of organizations, SPIN 2011, VIII skup privrednika i naučnika Operacioni menadžment u funkciji održivog ekonomskog rasta i razvoja Srbije 2011-2020, u Zbornik radova, FON, Privredna komora Srbije, Beograd, 2011.

[6] N. Petrović, M. Drakulić, V. Vujin, R. Drakulić, V. Jeremić, Climate Changes and green information technologies, Management - Journal for the theory and practice for Management, 2011, 59(XVI):35-43.
[7] World Commission on Environment and Development, Our Common Future, Oxford Paperbacks, London, 1987.

[8] A.Y. Hoekstra, The global dimension of water governance: Nine reasons for global arrangements in order to cope with local water problems, [Online], 2006,

http://doc.utwente.nl/58371/1/Report_20.pdf (accessed Apr. 15, 2012).

[9] M.P. Verkerk, A.Y. Hoekstra, P.W. Gerbens-Leenes, Global water governance: Conceptual design of global institutional arrangements, [Online], 2008,

http://www.waterfootprint.org/Reports/Report26-Verkerk-et-al2008GlobalWaterGovernance.pdf (accessed Apr. 4, 2012).

[10] A.Y Hoekstra, P.Q. Hung, Virtual water trade: A quantification of virtual water flows between nations in relation to international crop trade, [Online], 2002

http://www.waterfootprint.org/Reports/Report11.pdf, ～(accessed Feb. 7, 2012).

[11] A.Y., Hoekstra, A.K. Chapagain, The water footprints of Morocco and the Netherlands, Value of Water Research Report Series No.21, UNESCO-IHE, 2006.

[12] A.Y. Hoekstra, A.K. Chapagain, Water footprints of nations: water use by people as a function of their consumption pattern, Water Resour Manage, 2007, 21(1):35-48.

[13] A.K. Chapagain, A.Y. Hoekstra, Water footprints of nations, Value of water research report series no. 16. UNESCO-IHE, Delft, The Netherlands, 2004.

[14] W. Rees, M. Wackernagel, Ecological Footprints and appropriated carrying capacity: measuring the natural capacity requirements of the human economy, in Investing in Natural Capital, eds. A. Jansson,M. Hammer, C. Folke, and R. Costanza, Island Press, Washington DC, 1994.

[15] Water Resources Group, Charting our Water Future, 2009.

[16] Water Footprint Network, [Online], 2012, http://www.waterfootprint.org/?page=files/CorporateWaterFootpri nts, (accessed Feb. 7, 2012).

[17] ISO, [Online], 2012, http://www.iso.org/iso/isofocusplus_bonus_water-footprint, (accessed Apr. 7, 2012).

[18] G.R. Bradley, S. Pfister, Reducing humanity's water footprint, Environ. Sci. Technol. 44, 2010, 6019-6021. 